\title{
Geographic and seasonal variation of dissolved methane and aerobic methane oxidation in Alaskan lakes
}

\author{
K. Martinez-Cruz ${ }^{1,2}$, A. Sepulveda-Jauregui ${ }^{2}$, K. Walter Anthony ${ }^{2}$, and F. Thalasso ${ }^{1,2}$ \\ ${ }^{1}$ Biotechnology and Bioengineering Department, Cinvestav, 07360 Mexico City, D.F., Mexico \\ ${ }^{2}$ Water and Environmental Research Center, University of Alaska Fairbanks, P. O. Box 5860, 99775 Fairbanks, Alaska, USA \\ Correspondence to: F. Thalasso (thalasso@cinvestav.mx)
}

Received: 3 February 2015 - Published in Biogeosciences Discuss.: 9 March 2015

Revised: 16 July 2015 - Accepted: 22 July 2015 - Published: 4 August 2015

\begin{abstract}
Methanotrophic bacteria play an important role oxidizing a significant fraction of methane $\left(\mathrm{CH}_{4}\right)$ produced in lakes. Aerobic $\mathrm{CH}_{4}$ oxidation depends mainly on lake $\mathrm{CH}_{4}$ and oxygen $\left(\mathrm{O}_{2}\right)$ concentrations, in such a manner that higher MO rates are usually found at the oxic/anoxic interface, where both molecules are present. MO also depends on temperature, and via methanogenesis, on organic carbon input to lakes, including from thawing permafrost in thermokarst (thaw)-affected lakes. Given the large variability in these environmental factors, $\mathrm{CH}_{4}$ oxidation is expected to be subject to large seasonal and geographic variations, which have been scarcely reported in the literature. In the present study, we measured $\mathrm{CH}_{4}$ oxidation rates in 30 Alaskan lakes along a north-south latitudinal transect during winter and summer with a new field laser spectroscopy method. Additionally, we measured dissolved $\mathrm{CH}_{4}$ and $\mathrm{O}_{2}$ concentrations. We found that in the winter, aerobic $\mathrm{CH}_{4}$ oxidation was mainly controlled by the dissolved $\mathrm{O}_{2}$ concentration, while in the summer it was controlled primarily by the $\mathrm{CH}_{4}$ concentration, which was scarce compared to dissolved $\mathrm{O}_{2}$. The permafrost environment of the lakes was identified as another key factor. Thermokarst (thaw) lakes formed in yedoma-type permafrost had significantly higher $\mathrm{CH}_{4}$ oxidation rates compared to other thermokarst and non-thermokarst lakes formed in non-yedoma permafrost environments. As thermokarst lakes formed in yedoma-type permafrost have been identified to receive large quantities of terrestrial organic carbon from thaw and subsidence of the surrounding landscape into the lake, confirming the strong coupling between terrestrial and aquatic habitats and its influence on $\mathrm{CH}_{4}$ cycling.
\end{abstract}

\section{Introduction}

Northern lakes are an important source of atmospheric $\mathrm{CH}_{4}$ (Bastviken et al., 2011), and it has been estimated that they are responsible for as much as $6 \%$ of global emission to the atmosphere (Walter et al., 2007). Methane emission from aquatic ecosystems is significantly mitigated by $\mathrm{CH}_{4}$ oxidation (MO) by aerobic methanotrophs, a group of gramnegative bacteria that use $\mathrm{CH}_{4}$ as a carbon and energy source (Murrell et al., 1993; Trotsenko and Murrell, 2008). It has been estimated that globally, 30 to $99 \%$ of total $\mathrm{CH}_{4}$ produced in freshwater ecosystems is microbiologically oxidized in the water column rather than being released to the atmosphere (Bastviken et al., 2002; Thauer et al., 2008). Likewise, MO plays an important role in northern lakes specifically by oxidizing up to $88 \%$ of the $\mathrm{CH}_{4}$ diffusing through the water column (Kankaala et al., 2006, 2007; Bellido et al., 2011). As recently demonstrated using stable isotopes, after assimilating $\mathrm{CH}_{4}$, methanotrophs are incorporated into the lake food web by zooplankton (Kankaala et al., 2006; Jones and Grey, 2011), Daphnia magna (Taipale et al., 2012), Odonata spp. (Seifert and Scheu, 2012), and Chironomus larvae (Gentzel et al., 2012; Wooller et al., 2012), among others. In addition to $\mathrm{CH}_{4}$ respiration and conversion to $\mathrm{CO}_{2}$, $\mathrm{MO}$ is therefore a pathway that reincorporates a fraction of the $\mathrm{CH}_{4}-\mathrm{C}$ produced into the biogeochemical carbon cycle within lakes.

Several environmental factors directly affect aerobic MO in freshwater ecosystems. First, methanotrophy depends on the availability of both $\mathrm{CH}_{4}$ and $\mathrm{O}_{2}$. Higher $\mathrm{MO}$ rates are usually found at the oxic/anoxic interface, where both $\mathrm{CH}_{4}$ and $\mathrm{O}_{2}$ are present (Utsumi et al., 1998a, b; Bastviken et al., 2002; Liikanen et al., 2002; Carini et al., 2005; Schu- 


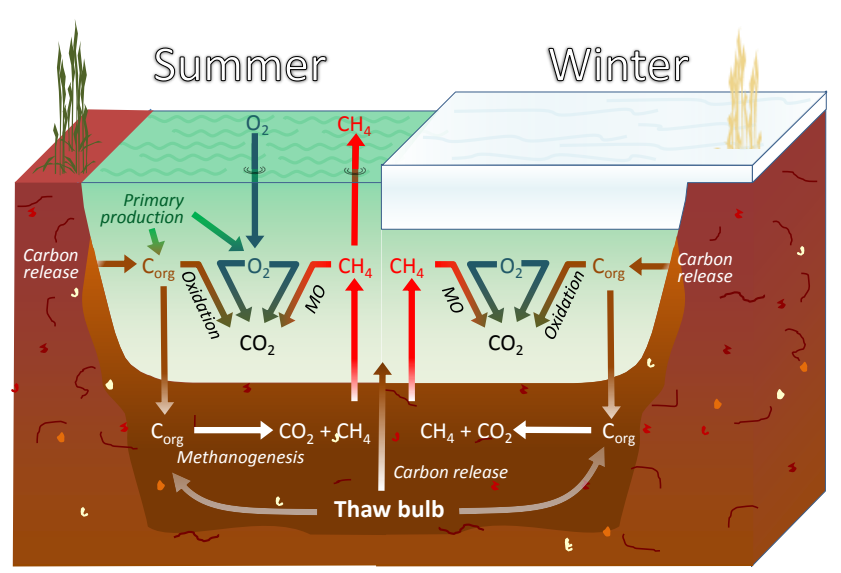

Figure 1. Carbon cycling in northern high-latitude lakes during the summer and winter. Carbon $\left(\mathrm{C}_{\text {org }}\right)$ release from primary production and landscape processes promotes $\mathrm{CH}_{4}$ production and competes with $\mathrm{MO}$ for $\mathrm{O}_{2}$.

bert et al., 2010). In turn, $\mathrm{CH}_{4}$ and $\mathrm{O}_{2}$ concentrations depend on numerous other processes involved in biogeochemical carbon cycling (Fig. 1). Among these, the most important are methanogenesis producing $\mathrm{CH}_{4}$, primary production and atmospheric diffusion supplying $\mathrm{O}_{2}$, and several aerobic metabolic processes that compete with $\mathrm{MO}$ for available $\mathrm{O}_{2}$ (Dzyuban, 2010).

In addition to autochthonous and allochthonous carbon inputs to lakes, permafrost thaw can provide an additional source of labile organic carbon to fuel methanogenesis and carbon mineralization in thermokarst (thaw) lakes (Zimov et al., 1997; Walter et al., 2006). MO in northern regions is therefore directly and indirectly linked to permafrost type and landscape processes that are highly variable. Permafrost ranges from sporadic to continuous and is also variable in composition (Jorgenson et al., 2008). Yedoma-type permafrost is an organic-rich (about $2 \%$ carbon by mass) Pleistocene-age permafrost with ice content of $50-90 \%$ by volume (Zimov et al., 2006), which occurs mainly in the previously unglaciated regions of Siberia, Alaska, and NW Canada (Czudek and Demek, 1970; Walter et al., 2007; Kanevskiy et al., 2011; Grosse et al., 2013). Non-yedoma permafrost has a more widespread distribution than yedoma permafrost and is also characterized by a much thinner carbon-rich horizon, variable in composition (Ping et al., 2008; Tarnocai et al., 2009; Hugelius et al., 2014).

Many northern lakes are located in continental climate zones, subject to contrasting seasonal conditions with long, cold winters followed by relatively short, but warm summers. Although psychrotolerant and psychrophilic methanotrophs have been reported (Omelchenko et al., 1993, 1996; Bowman et al., 1997; Trotsenko and Khmelenina, 2002), MO was reported to occur more efficiently at mesophilic temperature (Semrau et al., 2010). During winter, northern lakes are covered by a thick ice layer for 7 to 9 months. Surface lake ice impedes oxygen transfer from the atmosphere to the lake and, when snow-covered, substantially reduces light penetration and oxygen production by photosynthesis (White et al., 2008; Clilverd et al., 2009). Thus, the combination of low temperature and limited oxygen availability suggests lower MO rates in northern lakes in winter than in summer.

Given the number of parameters having a potential effect on MO, as well as the patchwork of seasonal and geographic conditions found among northern lakes, $\mathrm{MO}$ is expected to exhibit large geographic and seasonal variations that still remain to be characterized. The goal of our study was to determine these variations through measurement of dissolved $\mathrm{CH}_{4}$ and $\mathrm{O}_{2}$ as well as $\mathrm{MO}$ rates in the winter and summer in 30 lakes along a south-north transect in Alaska.

\section{Materials and methods}

\subsection{Site description}

We sampled 30 Alaskan lakes during two field campaigns, one in late winter (March-April 2011) and one in summer (June-July 2011). To evaluate the effects of latitudinal variation and permafrost type on MO, lakes were selected along a transect from the south-central Alaskan coast on the Kenai Peninsula to the Arctic Ocean near Prudhoe Bay (Fig. 2). The transect crossed through glaciated mountain ranges and discontinuous, sporadic, or no permafrost in south-central Alaska; discontinuous to isolated yedoma permafrost in the interior of Alaska; and continuous permafrost in northern Alaska. In this work, for simplicity, lakes located in yedoma-type permafrost areas will be referred to as yedoma lakes and all others as non-yedoma lakes. Geographic variability along the north-south Alaska transect has been previously described for ecosystems, climate, geology, and permafrost type (Gregory-Eaves et al., 2000; Jorgenson et al., 2008; Smith et al., 2010). Additionally, SepulvedaJauregui et al. (2015) quantified the surface area of the selected lakes $\left(0.002-1.45 \mathrm{~km}^{2}\right)$, their trophic states (ultraoligotrophic to eutrophic), and their annual $\mathrm{CH}_{4}$ fluxes (0.5$\left.317 \mathrm{~g} \mathrm{CH}_{4} \mathrm{~m}^{-2} \mathrm{yr}^{-1}\right)$. Table 1 shows the location and permafrost type of the selected lakes.

\subsection{Sampling and field measurements}

We sampled lake water usually near the center of each lake. In the winter, the ice cover was drilled through with a motorized auger $(0.3 \mathrm{~m}$ in diameter). Using a Hydrolab DataSonde (Hach Hydromet, Loveland, CO, USA), we measured temperature, $\mathrm{pH}$, chlorophyll $a$, and dissolved oxygen (DO). The $\mathrm{pH}$ and DO sensors of the Hydrolab were calibrated regularly, before and after each section of the latitudinal lake transect (four sections per transect, approximately one calibration per week). Temperature and chlorophyll $a$ sensors were not regularly calibrated. All parameters were measured at 0.5 or $1 \mathrm{~m}$ depth intervals throughout the water column, ex- 
Table 1. Identification, location, and permafrost soil type for lakes included in the study.

\begin{tabular}{llrll}
\hline$\#$ & Name & Lat. & Long. & Permafrost type \\
\hline 1 & Big Sky* A31 & 69.581 & -148.639 & Non-yedoma \\
2 & GTH 112 & 68.672 & -149.249 & Non-yedoma \\
3 & NE2 & 68.647 & -149.582 & Non-yedoma \\
4 & Toolik A28 & 68.632 & -149.605 & Non-yedoma \\
5 & E1 & 68.626 & -149.555 & Non-yedoma \\
6 & Julieta* A27 & 68.447 & -149.369 & Non-yedoma \\
7 & El Fuego* A36 & 67.666 & -149.716 & Non-yedoma \\
8 & Jonas* A26 & 67.647 & -149.722 & Non-yedoma \\
9 & Augustine Zoli* A25 & 67.138 & -150.349 & Non-yedoma \\
10 & Ping* & 67.136 & -150.370 & Non-yedoma \\
11 & Grayling* A24 & 66.954 & -150.393 & Non-yedoma \\
12 & Eugenia* & 65.834 & -149.631 & Yedoma \\
13 & Goldstream* & 64.916 & -147.847 & Yedoma \\
14 & Killarney* & 64.870 & -147.901 & Yedoma \\
15 & Smith A13 & 64.865 & -147.868 & Non-yedoma \\
16 & Stevens Pond* & 64.863 & -147.871 & Yedoma \\
17 & Duece A2 & 64.863 & -147.942 & Yedoma \\
18 & Ace A1 & 64.862 & -147.937 & Yedoma \\
19 & Rosie Creek* & 64.770 & -148.079 & Yedoma \\
20 & Otto & 63.842 & -149.037 & Non-yedoma \\
21 & Floatplane* A16 & 63.394 & -148.670 & Non-yedoma \\
22 & Montana A40 & 62.143 & -150.048 & Non-yedoma \\
23 & Rainbow Shore* A41 & 61.694 & -150.089 & Non-yedoma \\
24 & Big Merganser A49 & 60.726 & -150.644 & Non-yedoma \\
25 & Rainbow A48 & 60.719 & -150.808 & Non-yedoma \\
26 & Dolly Varden A47 & 60.704 & -150.787 & Non-yedoma \\
27 & Abandoned Cabin* A50 & 60.696 & -151.315 & Non-yedoma \\
28 & Scout A46 & 60.533 & -150.843 & Non-yedoma \\
29 & Engineer A45 & 60.478 & -150.323 & Non-yedoma \\
30 & Lower Ohmer A44 & 60.456 & -150.317 & Non-yedoma \\
\hline & & & & \\
\hline
\end{tabular}

* Indicates informal lake name.

cept in Dolly Varden L. where measurement intervals were increased to every five meters from 15 to $25 \mathrm{~m}$ depth. In lakes shallower than $1 \mathrm{~m}$, we measured Hydrolab parameters at three distributed depths throughout the lake water column.

Water samples for $\mathrm{MO}$ rates and dissolved $\mathrm{CH}_{4}$ concentration were taken at a depth of within $1 \mathrm{~m}$ of the ice-water interface in winter and usually at 0.75 to $1 \mathrm{~m}$ water depth in summer. Due to differences in lake depth and thickness of the ice sheets, samples reflected surface water in deep lakes, but mid water column or even lake bottom water environment, in shallow lakes. Samples were taken with a horizontal Van Dorn bottle (Wildco, Yulee, FL, USA).

Water density derived from surface and bottom water temperatures were used to determine the relative water column stability (RWCS; Padisak et al., 2003). Lakes with RWCS $>56.5$ were considered fully stratified, lakes with RWCS $<16.3$ were considered fully mixed, and lakes with intermediate RWCS were considered partially stratified (Branco et al., 2009). Similarly, we determined whether an oxycline was present in each lake based on a sharp DO gradient or presence of an oxic/anoxic interface. Detailed temperature and DO profiles are available as a Supplement in Sepulveda-Jauregui et al. (2015). We report all results in mean \pm standard deviation (SD).

\subsection{Dissolved $\mathrm{CH}_{4}$ concentration and $\mathrm{MO}$ rate}

To avoid long delays in sample transfer from remote locations to the laboratory, we determined dissolved $\mathrm{CH}_{4}$ concentrations with a previously described method based on Headspace Equilibration using Infrared Tunable Diode Laser Absorption Spectroscopy (HE-TDLAS; Sepulveda-Jauregui et al., 2012). This method consisted of creating a gas/liquid equilibrium in a $100 \mathrm{~mL}$ equilibration vial containing $60 \mathrm{~mL}$ of lake water sample and $40 \mathrm{~mL}$ of headspace (air) by vigorous shaking for $10 \mathrm{~s}$. As previously reported (SepulvedaJauregui et al., 2012), this shaking time was enough to reach equilibrium and allowed the non-invasive determination of $\mathrm{CH}_{4}$ concentration in the water sample by measuring headspace concentration with a laser beam crossing the headspace of the equilibration vial, through the glass walls 
of the vial. This measurement was conducted with a modified open-field $\mathrm{CH}_{4}$ analyzer (GasFinder 2; Boreal Laser, Edmonton, Canada). The $\mathrm{CH}_{4}$ concentration in the water sample was calculated from the measured headspace concentration according to Henry's law. In the present work, all $\mathrm{CH}_{4}$ concentrations are expressed in $\mathrm{mg} \mathrm{CH}_{4} \mathrm{~L}^{-1}$.

We determined duplicate $\mathrm{MO}$ rates in one water sample from each lake taken as described above, using a modified HE-TDLAS method to allow for measurement of MO in the field. This new method was based on a previous development using the HE-TDLAS method for the determination of methanogenic activity (Martinez-Cruz et al., 2012). Two $60 \mathrm{~mL}$ lake water subsamples from a single Van Dorn bottle sample were gently transferred to two $100 \mathrm{~mL}$ equilibration vials (duplicates). Equilibration vials were immediately closed with rubber stoppers and vigorously shaken for $10 \mathrm{~s}$ to transfer most of the dissolved $\mathrm{CH}_{4}$ contained in the water sample to the headspace. Next, the headspace was vented, the vial was closed, and the sample was shaken again to evacuate the residual $\mathrm{CH}_{4}$ content of the water sample. Using this procedure, more than $99.5 \%$ of the original $\mathrm{CH}_{4}$ content of the sample was evacuated. The equilibration vials were then closed with rubber stoppers and aluminum crimp caps, spiked with $0.6 \mathrm{~mL} \mathrm{CH}_{4}$ (99.0\% purity; Air Liquide, Houston, TX, USA) injected with a disposable syringe, and vigorously shaken for $10 \mathrm{~s}$. This approach allowed MO tests to be conducted with an initial standard $\mathrm{CH}_{4}$ concentration in the liquid phase $\left(\sim 0.6 \mathrm{mg} \mathrm{L}^{-1}\right)$. It also provided an initial $\mathrm{CH}_{4}$ to $\mathrm{O}_{2}$ molar ratio of 0.062 , significantly below the stoichiometric ratio (0.5), ensuring no $\mathrm{O}_{2}$ limitation.

Equilibration vials were incubated for 10-12 days in a water bath inside insulated boxes placed in our vehicle. In the winter, the vials were maintained at $2 \pm 2{ }^{\circ} \mathrm{C}$ in a water bath with ice supplements; in the summer, the vials were maintained at $15 \pm 2{ }^{\circ} \mathrm{C}$. The temperature of the water bath was measured daily. We measured the $\mathrm{CH}_{4}$ concentration in the equilibration vials daily using the HE-TDLAS method described in detail by Sepulveda-Jauregui et al. (2012). Briefly, dry control MO test vials containing only $\mathrm{CH}_{4}$ standards were read by the TDLAS for calibration. Each experimental equilibration vial was vigorously shaken for $10 \mathrm{~s}$ to reach phase equilibrium and then immediately placed in the laser beam path, after which a stable HE-TDLAS reading was typically observed within $5 \mathrm{~s}$. Five readings were taken for each MO test vial and recalibration was conducted after measuring each set of test vials to ensure instrument stability. The field HE-TDLAS method allowed measurement of dissolved $\mathrm{CH}_{4}$ and MO rates. This technique was simple, rapid (about $60 \mathrm{~s}$ per sample measurement), non-invasive, and avoided complications and long delays in sample transfer from remote locations to the laboratory.

We calculated the total $\mathrm{CH}_{4}$ concentration $\left(\mathrm{C}_{\mathrm{CH}_{4}}=\right.$ total $\mathrm{CH}_{4}$ mass present in the gas and liquid phases divided by the sample liquid volume) in each vial during the MO tests. MO rates were determined from the decrease in $C_{\mathrm{CH}_{4}}$ in the equilibration vials with time. MO rates determined by this method represent the MO rate after aeration and $\mathrm{CH}_{4}$ addition (vials spiked with $\mathrm{CH}_{4}$ and vigorously shaken). Thus, these MO rates do not correspond to actual observations of in situ DO and dissolved $\mathrm{CH}_{4}$ concentrations in the lakes. The measured $\mathrm{CH}_{4}$ oxidation rate was considered the potential $\mathrm{MO}\left(r_{\max } ; \mathrm{mg} \mathrm{CH}_{4} \mathrm{~L}^{-1} \mathrm{~d}^{-1}\right)$ under non-limiting $\mathrm{CH}_{4}$ and DO concentrations. To estimate the actual rate $(r$; $\mathrm{mg} \mathrm{CH} \mathrm{L}_{4}^{-1} \mathrm{~d}^{-1}$ ) from $r_{\max }$, a double Monod model was used (Bae and Rittmann, 1996; Segers, 1998) in which $C_{\mathrm{CH}_{4}}$ and $\mathrm{C}_{\mathrm{O}_{2}}$ represent the actual dissolved $\mathrm{CH}_{4}$ and $\mathrm{DO}$ concentrations measured in the lake, respectively, and $\mathrm{K}_{\mathrm{S}-\mathrm{CH}_{4}}$ and $\mathrm{K}_{\mathrm{S}-\mathrm{O}_{2}}$ are the apparent affinity constants of the methanotrophic community, for $\mathrm{CH}_{4}$ and DO, respectively:

$r=r_{\max } \cdot \frac{C_{\mathrm{CH}_{4}}}{K_{\mathrm{S}-\mathrm{CH}_{4}}+C_{\mathrm{CH}_{4}}} \cdot \frac{C_{\mathrm{O}_{2}}}{K_{\mathrm{S}-\mathrm{O}_{2}}+C_{\mathrm{O}_{2}}}$.

Average $K_{\mathrm{S}_{-} \mathrm{CH}_{4}}$ and $K_{\mathrm{S}-\mathrm{O}_{2}}$ values for lakes have been determined by previous studies: $K_{\mathrm{S}_{-} \mathrm{CH}_{4}}=0.110 \pm 0.053 \mathrm{mg} \mathrm{L}^{-1}$ (mean \pm SD; Liikanen et al., 2002; Lofton et al., 2014) and $K_{\mathrm{S}^{-O_{2}}}=0.624 \pm 0.064 \mathrm{mg} \mathrm{L}^{-1}$ (mean $\pm \mathrm{SD}$; Lidstrom and Somers, 1984; Frenzel et al., 1990). To the best of our knowledge, the highest $K_{\mathrm{S}-\mathrm{CH}_{4}}$ reported in lakes is $0.704 \mathrm{mg} \mathrm{L}^{-1}$ (Liikanen et al., 2002). It should be noted that these reported $K_{\mathrm{S}}$ values refer to the apparent affinity constants for the methanotrophic community, rather than the half-saturation constant for the $\mathrm{CH}_{4}$ monooxygenase enzyme that catalyzes $\mathrm{CH}_{4}$ oxidation. The potential error caused by using previously reported $K_{\mathrm{S}}$, instead of experimentally determined values will be considered in the discussion section.

To establish the extent of potential MO limitation by $\mathrm{CH}_{4}$ or DO, two limitation factors were defined, where $\beta$ is the limitation factor for $\mathrm{CH}_{4}(\%)$ and $\gamma$ is the limitation factor for DO (\%):

$0 \% \leq \beta=\left(1-\frac{C_{\mathrm{CH}_{4}}}{K_{{\mathrm{S}-\mathrm{CH}_{4}}+C_{\mathrm{CH}_{4}}}}\right) \cdot 100 \leq 100 \%$
$0 \% \leq \gamma=\left(1-\frac{C_{\mathrm{O}_{2}}}{K_{\mathrm{S}-\mathrm{O}_{2}}+C_{\mathrm{O}_{2}}}\right) \cdot 100 \leq 100 \%$.

A limitation factor of $100 \%$ means that $100 \%$ of a process ceases to occur due to the absence of the limiting substrate, while a limitation factor of $0 \%$ indicates a process occurring at maximum rate $\left(r=r_{\max }\right)$. When $\beta>\gamma, \mathrm{CH}_{4}$ was considered to be the limiting factor; conversely, when $\gamma>\beta$, DO was considered to be the limiting factor.

\subsection{Statistical analyses}

Normality was assessed by the Shapiro-Wilk test. Since most of the data was non-normally distributed and with unequal samples number, significant differences among all parameters were determined using Kruskal-Wallis multiple comparison test (differences were considered significant at $p<0.05, Z>1.96$ ). To assess whether $\mathrm{CH}_{4}$ was oxidized 
during the MO incubation tests, significant differences between $C_{\mathrm{CH}_{4}}$ were determined by an analysis of variance (ANOVA; $p<0.05$ ), after normality was assessed by the Shapiro-Wilk test. Statistical analyses were conducted using the NCSS 2000 Statistical Analysis System software (Number Cruncher Statistical Systems, Kaysville, UT, USA). Linear regressions were also conducted to determinate the MO rates using Wolfram Mathematica 7.0 (Wolfram, Minneapolis, MN, USA).

\section{Results}

\subsection{Physicochemical parameters}

The sampled lakes were shallow; other than four atypical lakes with a maximum known depth of $>20 \mathrm{~m}$ (lakes \#4, \#24, \#26 and \#30), the average lake depth in summer was $4.5 \pm 2.6 \mathrm{~m}$ (mean $\pm \mathrm{SD}$ ). During winter, none of the lakes was completely frozen at the sampling stations. Liquid water was always present underneath the ice cover, which ranged in thickness from 0.60 to $1.25 \mathrm{~m}$ (mean $\pm \mathrm{SD}$, $0.81 \pm 0.14 \mathrm{~m}$ ). The mean temperature, measured at all depth throughout the lake water columns with the Hydrolab probe was $2.4 \pm 0.6^{\circ} \mathrm{C}$ (mean $\pm \mathrm{SD}, n=103$ ) in the winter and $13.9 \pm 2.4^{\circ} \mathrm{C}$ (mean $\pm \mathrm{SD}, n=235$ ) in the summer. According to RWCS, during the summer, 15 lakes of the 28 for which a complete temperature profile was determined were fully thermally stratified. Six lakes were partially stratified and seven lakes were mixed. During the winter, 16 of 18 lakes for which a complete temperature profile was determined were fully mixed, while two lakes were partially stratified and none was fully stratified. We observed temperature inversion in 15 of the 18 lakes, with temperature gradients ranging from -0.1 to $-3.4^{\circ} \mathrm{C}$, with an average of $-1.4^{\circ} \mathrm{C}$ (top minus bottom temperature). Overall, only one third of the temperature profiles indicated clear stratification. In both seasons, no correlation between RWCS and lake depth was found, probably due to the fact that lakes were shallow and with an uneven depth distribution.

Lake water $\mathrm{pH}$ ranged from 5.9 to 8.2 in winter and 6.3 to 9.2 in summer among the study lakes. Chlorophyll $a$ was only detected during the summer, ranging from 1.0 to $45.9 \mu \mathrm{g} \mathrm{L}^{-1}$ (manufacturer detection limit, $0.03 \mu \mathrm{g} \mathrm{L}^{-1}$ ). The concentration of dissolved $\mathrm{CH}_{4}$ in the 30 lakes ranged from 0.01 to $14.77 \mathrm{mg} \mathrm{L}^{-1}$ during the winter and from 0.02 to $1.51 \mathrm{mg} \mathrm{L}^{-1}$ during the summer (Table 2). The DO concentration at the same depths ranged from 0.10 to $13.63 \mathrm{mg} \mathrm{L}^{-1}$ during the winter and from 0.22 to $11.07 \mathrm{mg} \mathrm{L}^{-1}$ during the summer (Table 2). During summer, a clear oxycline was observed in all yedoma lakes, but only in six of 20 non-yedoma lakes. In contrast, during winter, an oxycline was not observed in any of the yedoma lakes, which were largely anaerobic throughout the whole water column. We observed an oxycline in winter in four of 13 non-yedoma lakes. Over-

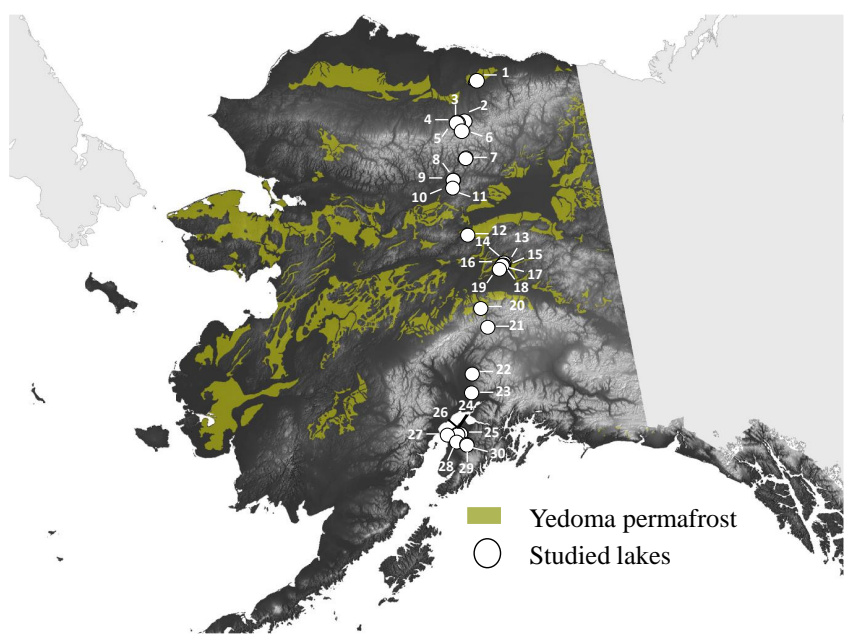

Figure 2. Locations of studied Alaskan lakes (white circles) plotted on the Alaska DEM hillshade raster. Information about the distribution of yedoma-type deposits (Pleistocene-aged, ice-rich silt containing deep thermokarst lakes) was from Jorgenson et al. (2008) and Kanevskiy et al. (2011). The Alaska map is the National Elevation Data Set $30 \mathrm{~m}$ hillshade raster.

all, an oxycline was observed in $30 \%$ of the DO profiles. Temperature-oxygen profiles for all 30 studied lakes are shown in Sepulveda-Jauregui et al. (2015).

Fig. 3 shows the statistical distributions of the dissolved $\mathrm{CH}_{4}$ and DO concentrations, as well as the Kruskal-Wallis comparisons. Significant differences were observed between yedoma and non-yedoma lakes $(p<0.05)$. In yedoma lakes, the $\mathrm{CH}_{4}$ and DO concentrations were significantly higher and lower, respectively, than in non-yedoma lakes during both seasons (Kruskal-Wallis test, $p<0.05$ ). In addition to differences related to permafrost type, higher $\mathrm{CH}_{4}$ concentrations and lower DO concentrations were observed during the winter than in the summer (Fig. 3) and an apparent geographic trend was observed. Higher dissolved $\mathrm{CH}_{4}$ and lower DO concentrations were found in lakes from central Alaska than in those from southern and northern Alaska (SepulvedaJauregui et al., 2015).

\subsection{Methane oxidation rates}

The HE-TDLAS method allowed us to determine the MO potential in the field in all studied lakes. Fig. 4 shows three representative $C_{\mathrm{CH}_{4}}$ trends observed in the MO vials. In some cases, MO began on the first day of incubation (Fig. 4a) and the initial slope of the change in $C_{\mathrm{CH}_{4}}$ was taken into account in determining the MO rate. In about $60 \%$ of the cases during the summer and $80 \%$ during the winter, a lag phase was observed; i.e. period of time with no apparent MO (Fig. 4b). This behavior, termed induction of MO, has previously been reported for various soils (Bender and Conrad, 1995; Dunfield et al., 1999) and can be interpreted as an adaptation period of the $\mathrm{CH}_{4}$ oxidizers to the culture conditions. In lakes in 
Table 2. Methane oxidation parameters for 30 Alaskan lakes.

\begin{tabular}{|c|c|c|c|c|c|c|c|c|c|c|}
\hline \multirow[b]{2}{*}{ \# } & \multicolumn{2}{|c|}{$\mathrm{CH}_{4}\left(\mathrm{mg} \mathrm{L}^{-1}\right)$} & \multicolumn{2}{|c|}{$\mathrm{O}_{2}\left(\mathrm{mg} \mathrm{L}^{-1}\right)$} & \multicolumn{2}{|c|}{$\begin{array}{l}\text { Potential MO } \\
\left(\mathrm{mg} \mathrm{L}^{-1} \mathrm{~d}^{-1}\right)\end{array}$} & \multicolumn{2}{|c|}{$\begin{array}{c}\text { Actual MO } \\
\left(\mathrm{mg} \mathrm{L}^{-1} \mathrm{~d}^{-1}\right)\end{array}$} & \multicolumn{2}{|c|}{ Limiting factor } \\
\hline & Winter & Summer & Winter & Summer & Winter & Summer & Winter & Summer & Winter & Summer \\
\hline 1 & 6.43 & 0.05 & 0.13 & 10.53 & 0.23 & 0.11 & 0.08 & 0.03 & $\mathrm{O}_{2}$ & $\mathrm{CH}_{4}$ \\
\hline 2 & 0.58 & 0.09 & 0.43 & 8.28 & 0.14 & 0.36 & 0.05 & 0.15 & $\mathrm{O}_{2}$ & $\mathrm{CH}_{4}$ \\
\hline 3 & 0.02 & 0.05 & 1.73 & 9.80 & 0.12 & 0.07 & 0.02 & 0.02 & $\mathrm{CH}_{4}$ & $\mathrm{CH}_{4}$ \\
\hline 4 & 0.11 & 0.03 & 10.09 & 9.46 & BDL & 0.28 & 0.00 & 0.06 & $\mathrm{CH}_{4}$ & $\mathrm{CH}_{4}$ \\
\hline 5 & 0.05 & 0.04 & 9.59 & 9.52 & 0.10 & 0.19 & 0.03 & 0.05 & $\mathrm{CH}_{4}$ & $\mathrm{CH}_{4}$ \\
\hline 6 & 0.08 & 0.07 & ND & 9.81 & 0.12 & 0.20 & $\mathrm{ND}$ & 0.09 & ND & $\mathrm{CH}_{4}$ \\
\hline 7 & ND & 0.06 & ND & 9.65 & ND & 0.18 & ND & 0.04 & ND & $\mathrm{CH}_{4}$ \\
\hline 8 & 3.68 & 0.03 & 13.63 & 10.30 & 0.03 & 0.18 & 0.03 & 0.04 & $\mathrm{O}_{2}$ & $\mathrm{CH}_{4}$ \\
\hline 9 & 8.83 & 0.11 & 3.64 & 9.87 & 0.05 & 0.39 & 0.04 & 0.19 & $\mathrm{O}_{2}$ & $\mathrm{CH}_{4}$ \\
\hline 10 & 3.00 & 0.06 & 0.25 & 6.94 & 0.11 & 0.11 & 0.03 & 0.03 & $\mathrm{O}_{2}$ & $\mathrm{CH}_{4}$ \\
\hline 11 & 8.43 & 0.88 & 0.19 & 9.31 & BDL & 0.28 & 0.00 & 0.23 & $\mathrm{O}_{2}$ & $\mathrm{CH}_{4}$ \\
\hline 12 & 0.79 & 0.07 & 0.15 & 6.90 & 0.09 & 0.29 & 0.02 & 0.11 & $\mathbf{O}_{2}$ & $\mathrm{CH}_{4}$ \\
\hline 13 & 8.43 & 0.19 & 0.11 & 6.23 & 0.49 & 0.54 & 0.07 & 0.48 & $\mathrm{O}_{2}$ & $\mathrm{O}_{2}$ \\
\hline 14 & 12.59 & 0.31 & 0.09 & 0.31 & 0.20 & 0.92 & 0.03 & 0.30 & $\mathrm{O}_{2}$ & $\mathrm{O}_{2}$ \\
\hline 15 & 1.30 & 0.02 & 0.23 & 3.93 & 0.05 & 0.31 & 0.01 & 0.05 & $\mathrm{O}_{2}$ & $\mathrm{CH}_{4}$ \\
\hline 16 & ND & 0.72 & 0.11 & 1.36 & ND & 0.34 & ND & 0.20 & ND & $\mathbf{O}_{2}$ \\
\hline 17 & 6.60 & 0.59 & 0.19 & 0.57 & 0.06 & 1.34 & 0.01 & 0.54 & $\mathbf{O}_{2}$ & $\mathrm{O}_{2}$ \\
\hline 18 & 0.70 & 0.03 & 0.14 & 6.74 & 0.02 & 0.77 & 0.00 & 0.15 & $\mathrm{O}_{2}$ & $\mathrm{CH}_{4}$ \\
\hline 19 & 14.77 & 1.51 & 0.13 & 0.22 & 0.20 & 0.74 & 0.04 & 0.19 & $\mathbf{O}_{2}$ & $\mathbf{O}_{2}$ \\
\hline 20 & 1.24 & 0.03 & 0.31 & 9.47 & 0.05 & 0.67 & 0.01 & 0.15 & $\mathrm{O}_{2}$ & $\mathrm{CH}_{4}$ \\
\hline 21 & $\mathrm{ND}$ & 0.04 & ND & 9.52 & ND & 0.33 & $\mathrm{ND}$ & 0.08 & ND & $\mathrm{CH}_{4}$ \\
\hline 22 & 0.08 & 0.05 & 2.79 & 11.07 & 0.05 & 0.20 & 0.01 & 0.06 & $\mathrm{CH}_{4}$ & $\mathrm{CH}_{4}$ \\
\hline 23 & 0.30 & 0.08 & 5.84 & 9.59 & 0.02 & 0.68 & 0.01 & 0.33 & $\mathrm{CH}_{4}$ & $\mathrm{CH}_{4}$ \\
\hline 24 & 0.04 & 0.02 & 12.40 & 9.66 & 0.06 & 0.34 & 0.02 & 0.08 & $\mathrm{CH}_{4}$ & $\mathrm{CH}_{4}$ \\
\hline 25 & 0.08 & 0.03 & 11.91 & 10.20 & 0.32 & 0.25 & 0.12 & 0.04 & $\mathrm{CH}_{4}$ & $\mathrm{CH}_{4}$ \\
\hline 26 & 0.01 & 0.03 & 10.00 & 10.24 & 0.04 & 0.08 & 0.00 & 0.02 & $\mathrm{CH}_{4}$ & $\mathrm{CH}_{4}$ \\
\hline 27 & 0.03 & 0.02 & 7.90 & 9.67 & 0.15 & 0.41 & 0.03 & 0.07 & $\mathrm{CH}_{4}$ & $\mathrm{CH}_{4}$ \\
\hline 28 & 0.07 & 0.04 & 0.20 & 9.01 & BDL & 0.38 & 0.00 & 0.09 & $\mathrm{O}_{2}$ & $\mathrm{CH}_{4}$ \\
\hline 29 & 0.04 & 0.04 & 9.13 & 10.19 & 0.02 & 0.28 & 0.00 & 0.05 & $\mathrm{CH}_{4}$ & $\mathrm{CH}_{4}$ \\
\hline \multirow[t]{2}{*}{30} & ND & 0.03 & ND & 10.25 & ND & 0.38 & ND & 0.11 & ND & $\mathrm{CH}_{4}$ \\
\hline & \multicolumn{10}{|c|}{ Mean } \\
\hline Global & 3.29 & 0.47 & 3.91 & 7.95 & 0.10 & 0.39 & 0.03 & 0.13 & $\mathrm{O}_{2}^{*}$ & $\mathrm{CH}_{4}^{*}$ \\
\hline Yedoma & 7.53 & 1.73 & 0.14 & 3.19 & 0.18 & 0.71 & 0.03 & 0.28 & $\mathrm{O}_{2}^{*}$ & $\mathrm{CH}_{4}^{*}$ \\
\hline Non-yedoma & 2.02 & 0.09 & 5.30 & 9.40 & 0.08 & 0.29 & 0.03 & 0.09 & $\mathrm{CH}_{4}^{*}$ & $\mathrm{CH}_{4}^{*}$ \\
\hline
\end{tabular}

* Indicates median; ND - Not determined; BDL - Bellow detection limit. Yedoma lakes are marked in bold font.

which this pattern was observed, the lag phase was not taken into account and the MO rate was instead determined from the slope of $C_{\mathrm{CH}_{4}}$ after the lag phase. When no significant decrease in $C_{\mathrm{CH}_{4}}$ was observed during the first 7 days (Fig. 4c; ANOVA , $p<0.05$ ), we assumed an MO rate of zero, consistent with previous reports for various soils (Whalen et al., 1990; Bender and Conrad, 1995; Dunfield et al., 1999). We observed MO rates of zero in only three non-yedoma lakes during winter. Otherwise, no correlation with lake morphology, season, or permafrost type was observed in regard to the existence of a lag phase or its duration.

The potential MO rate $r_{\max }$ ranged from 0.000 to $0.488 \mathrm{mg} \mathrm{L}^{-1} \mathrm{~d}^{-1}$ during the winter and from 0.073 to
$1.339 \mathrm{mg} \mathrm{L}^{-1} \mathrm{~d}^{-1}$ during the summer (Fig. 5a). Seasonal variation of $r_{\max }$ was significant, with summer $r_{\max }$ up to 47 times higher than winter rates. Permafrost type was also an important determining factor, because during the summer, yedoma lakes had higher $r_{\max }$ than non-yedoma lakes (Kruskal-Wallis test, $p<0.05$ ); specifically, $r_{\max }$ was $0.71 \pm 0.36$ and $0.29 \pm 0.16 \mathrm{mg} \mathrm{L}^{-1} \mathrm{~d}^{-1}$ (mean $\pm \mathrm{SD}$ ) for yedoma and non-yedoma lakes, respectively. However, during the winter, no significant differences were observed between yedoma and non-yedoma lakes. In addition to differences related to permafrost type, an apparent latitudinal pattern was also observed, with higher $r_{\max }$ for lakes from cen- 


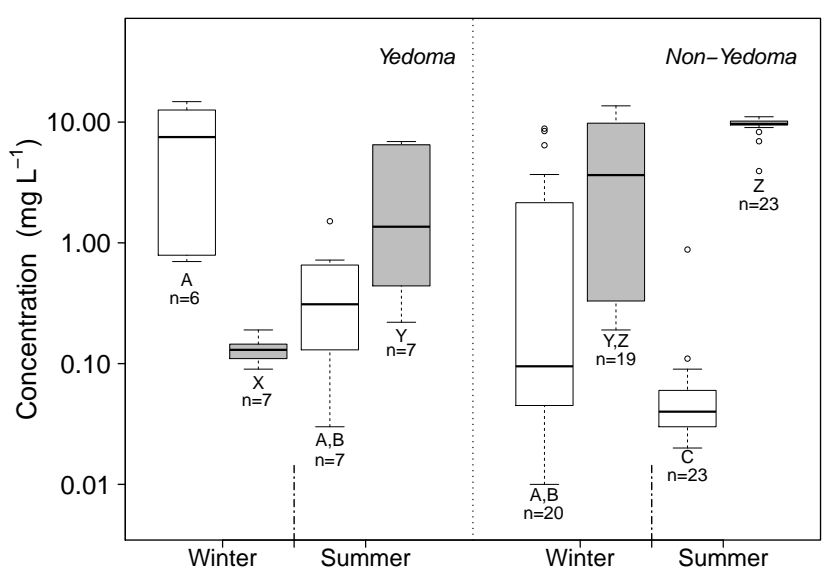

Figure 3. Statistical distributions of $\mathrm{CH}_{4}$ (white boxes) and DO (grey boxes) water concentrations in yedoma and non-yedoma lakes during the winter and summer. The boxes include the median (Q2) and the quartile range (Q1 and Q3). The whiskers show minimum and maximum data. The open circles show outlier data. Capital letters are Kruskal-Wallis multiple comparison test; values with the same capital letter are not significantly different $(p<0.05$, $Z>1.96) . n$ represents the number of lakes measured.

tral Alaska compared to those from southern and northern Alaska (Fig. 5a).

\section{Discussion}

\subsection{Geographic and seasonal variations in physicochemical parameters}

In yedoma lakes, the $\mathrm{CH}_{4}$ and $\mathrm{DO}$ concentrations were significantly higher and lower, respectively, than in non-yedoma lakes during both seasons. This observation is most likely due to higher organic carbon and nutrient inputs associated with thawing permafrost in yedoma-type lakes. Walter Anthony et al. (2014) and Sepulveda-Jauregui et al. (2015) showed that thawing yedoma permafrost not only provides ancient (Pleistocene-aged) organic carbon stimulating $\mathrm{CH}_{4}$ production but also phosphate and nitrogen (ammonium), which promotes bacterial, algal and contemporary plant growth in and around lakes. Since terrestrial plant matter surrounding lakes gets deposited in thermokarst-lake sediments as lakes laterally expand, both enhanced allochthonous and autochthonous productivity of yedoma-type lake ecosystems results in higher rates of contemporary organic matter loading to sediments of yedoma-type lakes compared to nonyedoma lakes (Walter Anthony et al., 2014). Contemporary organic matter decomposes in part to form $\mathrm{CH}_{4}$ in surface lake sediments. In contrast, ancient yedoma carbon is decomposed throughout the sediment profile (Fig. 1), with particularly high rates of methanogenesis occurring along the permafrost thaw front, located deep in the thaw bulb beneath the lake (Heslop et al., 2015). Methane produced at depth in

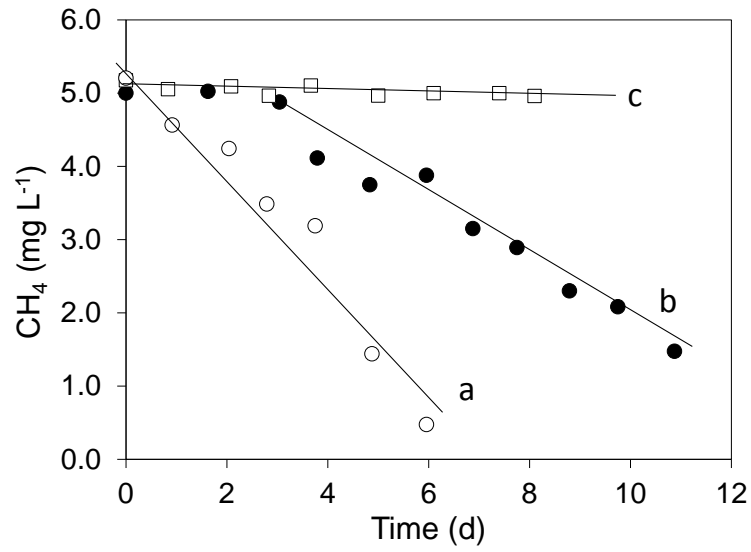

Figure 4. Examples of $\mathrm{CH}_{4}$ oxidation patterns observed during the MO assays: (a) assay with no lag-phase, (b) assay with a 3-day lag-phase, and (c) assay with no detected activity. Straight lines are linear correlations.

the thaw bulb subsequently migrates, primarily as free-phase bubbles through bubble tubes in sediments, to the surface sediments where it escapes the lake via ebullition (Walter Anthony and Anthony, 2013; Tan et al. 2015). Thus, higher organic carbon and nutrient inputs in yedoma-type lakes promote higher anaerobic metabolism in the sediments together with aerobic metabolism in the water column, leading to higher $\mathrm{CH}_{4}$ and lower DO concentrations in the water column.

In both yedoma and non-yedoma lakes, higher $\mathrm{CH}_{4}$ concentrations and lower DO concentrations were observed during the winter than in the summer (Fig. 3). This seasonal variation can be attributed to thick ice covering the lakes in winter. Ice cover impedes gas exchange between the water and the atmosphere, promoting $\mathrm{CH}_{4}$ build-up in the water column (Phelps et al., 1998; Bastviken et al., 2004; Juutinen et al., 2009) and hindering $\mathrm{O}_{2}$ transfer from the atmosphere, except in some locations where high-flux ebullition seeps allow gas exchange through local holes in lake ice (Greene et al., 2014). Ice and snow also reduce light penetration and oxygen production by photosynthesis beneath the ice (White et al., 2008; Clilverd et al., 2009). The absence of detectable levels of chlorophyll $a$ in ice-covered lakes during March and April (see results section) despite the longer springtime photoperiod was supportive evidence of reduced photosynthesis under the ice. In summer, although $\mathrm{CH}_{4}$ production was probably higher due to warmer sediments, it did not cumulate in the water column and was released to the atmosphere (Fig. 1).

Geographic variations were also observed with higher dissolved $\mathrm{CH}_{4}$ and lower DO concentrations being found in lakes from central Alaska than in those from southern and northern Alaska. However, this apparent latitudinal pattern was related to the higher proportion of yedoma lakes in central Alaska. No significant latitudinal trend was observed 

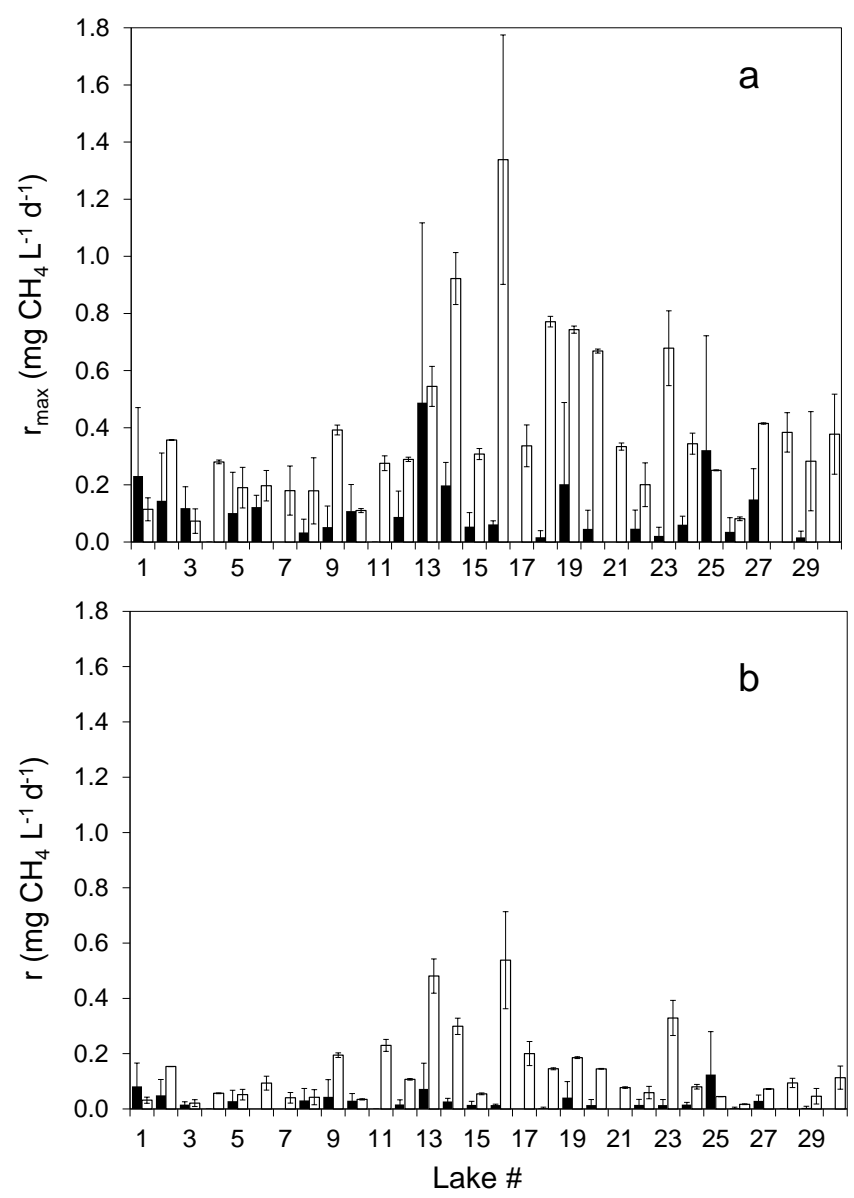

Figure 5. (a) $\mathrm{CH}_{4}$ oxidation potential $\left(r_{\max }\right)$ and (b) $\mathrm{CH}_{4}$ oxidation rates observed in 30 lakes along a north-south transect (left-right) in Alaska during the summer (white bars) and the winter (black bars).

when yedoma and non-yedoma lakes were analyzed separately (Kruskal-Wallis test, $p<0.05$ ).

Figure 3 shows that when relatively high $\mathrm{CH}_{4}$ concentrations were found, relatively low DO concentrations were observed and vice versa. This pattern was particularly clear in yedoma lakes: in winter, a $\mathrm{CH}_{4}$ concentration of $7.32 \pm 5.86 \mathrm{mg} \mathrm{L}^{-1}$ (mean $\pm \mathrm{SD}$ ) was found, while the DO concentration was $0.13 \pm 0.03 \mathrm{mg} \mathrm{L}^{-1}$ (mean $\pm \mathrm{SD}$ ). In the same yedoma lakes, the summer $\mathrm{CH}_{4}$ concentration was $0.49 \pm 0.52 \mathrm{mg} \mathrm{L}^{-1}$ (mean $\pm \mathrm{SD}$ ), while the DO concentration was $3.19 \pm 3.24 \mathrm{mg} \mathrm{L}^{-1}$ (mean $\pm \mathrm{SD}$ ). This observation suggests that $\mathrm{MO}$ was a significant contributor of the biogeochemical processes, actively controlling $\mathrm{O}_{2}$ and $\mathrm{CH}_{4}$ concentrations by oxidizing $\mathrm{CH}_{4}$ when $\mathrm{O}_{2}$ was present. To confirm the latter, it would be necessary to measure experimentally the $\mathrm{O}_{2}$ uptake rate by methanotrophs and by other aerobic processes that compete with MO (Dzyuban, 2010).

The trend toward higher $\mathrm{CH}_{4}$ concentrations and lower DO concentrations in winter than in summer was not as strong in non-yedoma lakes as in yedoma lakes (Fig. 4). These results provide additional evidence that in non-yedoma lakes, the lower organic carbon inputs fuels more weakly methanogenesis and aerobic processes including MO than in yedoma lakes, resulting in a lower seasonal variation of $\mathrm{CH}_{4}$ and DO concentration. Another reason is that yedoma lakes have a significantly higher ebullition year round (Walter et al., 2007; Sepulveda-Jauregui et al., 2015). Even during winter, Greene et al. (2014) found that $80 \%$ of $\mathrm{CH}_{4}$ in ebullition bubbles trapped under the ice cover dissolves into the lake water column before being confined within the growing ice sheet, leading to elevated dissolved $\mathrm{CH}_{4}$ beneath the ice.

\subsection{Limiting factors of MO rates}

The actual MO rates $r$ ranged from 0.000 to $0.124 \mathrm{mg} \mathrm{L}^{-1} \mathrm{~d}^{-1}$ during the winter and from 0.017 to $0.538 \mathrm{mg} \mathrm{L}^{-1} \mathrm{~d}^{-1}$ during the summer (Fig. 6b), which as expected were significantly lower than the potential MO rates. These $r$ values are within the range reported for arctic lakes, which ranges over 3 magnitude order, from 0.001 to $1 \mathrm{mg} \mathrm{L}^{-1} \mathrm{~d}^{-1}$ (Liikanen et al., 2002; Kankaala et al., 2006; Lofton et al., 2014). Similarly, $r$ values were 1 to 50-fold higher in the summer than in the winter. We attribute this finding to the temperature dependence of methanotrophy (Semrau et al., 2008; Borrel et al., 2011), but also to the limited DO concentration under the ice cover during the winter.

In addition to seasonal variations, permafrost type was also a determining factor of $r$ and $r_{\max }$. As mentioned before, although no difference in $r_{\max }$ was observed during winter between yedoma and non-yedoma lakes, $r_{\max }$ in yedoma lakes was about twice as high than in nonyedoma lakes during summer. We attribute that difference to a more active MO methanotrophic community in yedoma lakes, as all $r_{\max }$ tests were conducted in aerated vials with an initial standard $\mathrm{CH}_{4}$ concentration in the liquid phase $\left(\sim 0.6 \mathrm{mg} \mathrm{L}^{-1}\right)$, thus ensuring similar and non-limiting conditions. As observed with $r_{\max }$, during summer yedoma lakes showed 2-3 times higher $r$ than non-yedoma lakes (KruskalWallis test, $p<0.05 ; r=0.28 \pm 0.17$, mean $\pm \mathrm{SD}$, yedoma lakes; $r=0.09 \pm 0.08 \mathrm{mg} \mathrm{L}^{-1} \mathrm{~d}^{-1}$, mean $\pm \mathrm{SD}$, non-yedoma lakes). Higher $r$ values for yedoma lakes in summer is explained by the higher dissolved $\mathrm{CH}_{4}$ concentration in presence of a relatively high DO concentration above the oxycline (Fig. 3). As observed with $\mathrm{CH}_{4}$ and DO concentrations, no significant latitudinal trend in MO was observed, when yedoma and non-yedoma lakes were analyzed separately.

The actual MO rates; $r$, were determined from $r_{\max }$ and $\mathrm{CH}_{4}$ and DO concentrations using two affinity constants, $K_{\mathrm{S}-\mathrm{CH}_{4}}$ and $K_{\mathrm{S}-\mathrm{O}_{2}}$. These affinity constants are highly variable, because their determination is challenging and subject to relatively high determination error (Segers et al., 1998) and because the methanotrophic community is sensitive to numerous factors and changes over time and space (Carini et al., 2005; He et al., 2012). For instance, Lofton et al. (2014) reported a variation of $150 \%$ in $K_{\mathrm{S}-\mathrm{CH}_{4}}$ within the hypolim- 
netic water column of two lakes with similar characteristics. The determination of MO rates may, therefore, be subject to large error if reported values are used instead of experimental parameters or because of standard error associated to experimental $K_{\mathrm{S}}$ determination (Kovarova-Kovar and Egli, 1998). To quantify these potential errors, a sensitivity analysis was conducted. We arbitrarily modified $\mathrm{K}_{\mathrm{S}-\mathrm{CH}_{4}}$ and $\mathrm{K}_{\mathrm{S}-\mathrm{O}_{2}}$ and calculated the resulting $r$ (Eq. 1) using the experimental $r_{\max }$, $C_{\mathrm{CH}_{4}}$, and $C_{\mathrm{O}_{2}}$ measured in the 30 lakes. Figure 6 shows the error on $r$ caused by a given error on $K_{\mathrm{S}-\mathrm{O}_{2}}$ (Fig. 6a) and $K_{\mathrm{S}-\mathrm{CH}_{4}}$ (Fig. 6b), for yedoma and non-yedoma lakes, in winter and in summer. According to this analysis, an underestimation of $K_{\mathrm{S}-\mathrm{O}_{2}}$ or $K_{\mathrm{S}-\mathrm{CH}_{4}}$ would lead to an overestimation of the actual MO rate (positive error), while an overestimation of these affinity constants would produce an underestimation of $r$ (negative error). Fig. 6a shows that, an error on $K_{\mathrm{S}-\mathrm{O}_{2}}$ ranging from -50 to $200 \%$, would cause from 10 to $-6 \%$ error on $r$, for all lakes and all seasons, except in yedoma lakes during winter, where an error from 75 to $-50 \%$ would be generated. This relatively high sensitivity of $r$ to error in $K_{\mathrm{S}_{-} \mathrm{O}_{2}}$ in yedoma lakes during winter is due to DO concentrations close to $K_{\mathrm{S}-\mathrm{O}_{2}}$. Likewise, Fig. 6b shows that, from an error on $\mathrm{K}_{\mathrm{S}-\mathrm{CH}_{4}}$ ranging from -50 to $200 \%$, a resulting error on $r$ from 6 to $-4 \%$ would be done, for all lakes and all seasons, except in non-yedoma lakes during summer, where an error from 50 to $-34 \%$ would be generated. As above, the latter is due to $\mathrm{CH}_{4}$ concentrations close to $K_{\mathrm{S}-\mathrm{CH}_{4}}$ in non-yedoma lakes during summer. This sensitivity analysis shows that, other than for $K_{\mathrm{S}-\mathrm{O}_{2}}$ in yedoma lakes during winter and $\mathrm{K}_{\mathrm{S}-\mathrm{CH}_{4}}$ in non-yedoma lakes during summer, errors on $K_{\mathrm{S}}$ would have relatively little impact on determination of methanotrophic rates. The potentially significant error on methanotrophic rates in yedoma lakes during winter and in non-yedoma lakes during summer encourages further studies including experimental $K_{S}$ determination.

From Eqs. (2) and (3), we estimated that, during the summer $\mathrm{CH}_{4}$ was the main limiting factor in 25 out of 30 lakes. In contrast, during winter, $\mathrm{CH}_{4}$ was the main limiting factor in 10 of 26 lakes (Table 2). Notably, during the winter, DO was the limiting factor of MO for all seven yedoma lakes, while during the summer, $\mathrm{CH}_{4}$ was the limiting factor for all non-yedoma lakes. A similar error analysis was done on $\beta$ and $\gamma$, as done with $r$, to estimate if the estimated limiting factor would change as a result of error on $K_{\mathrm{S}}$ ranging from -50 to $200 \%$. The results showed no impact on the limiting factor in the 30 lakes and for both seasons. These results confirm that $\mathrm{MO}$ was mainly controlled by $\mathrm{DO}$ and $\mathrm{CH}_{4}$ availability, which in turn depended on the season and landscape processes.

A potential bias in our $r$ estimates may have arisen from taking water samples at a single depth in each lake. The literature has clearly shown that a higher MO rate is often found at the oxic/anoxic interface in stratified lakes (Utsumi et al., 1998a, b; Bastviken et al. 2002; Carini et al., 2005; Pimenov
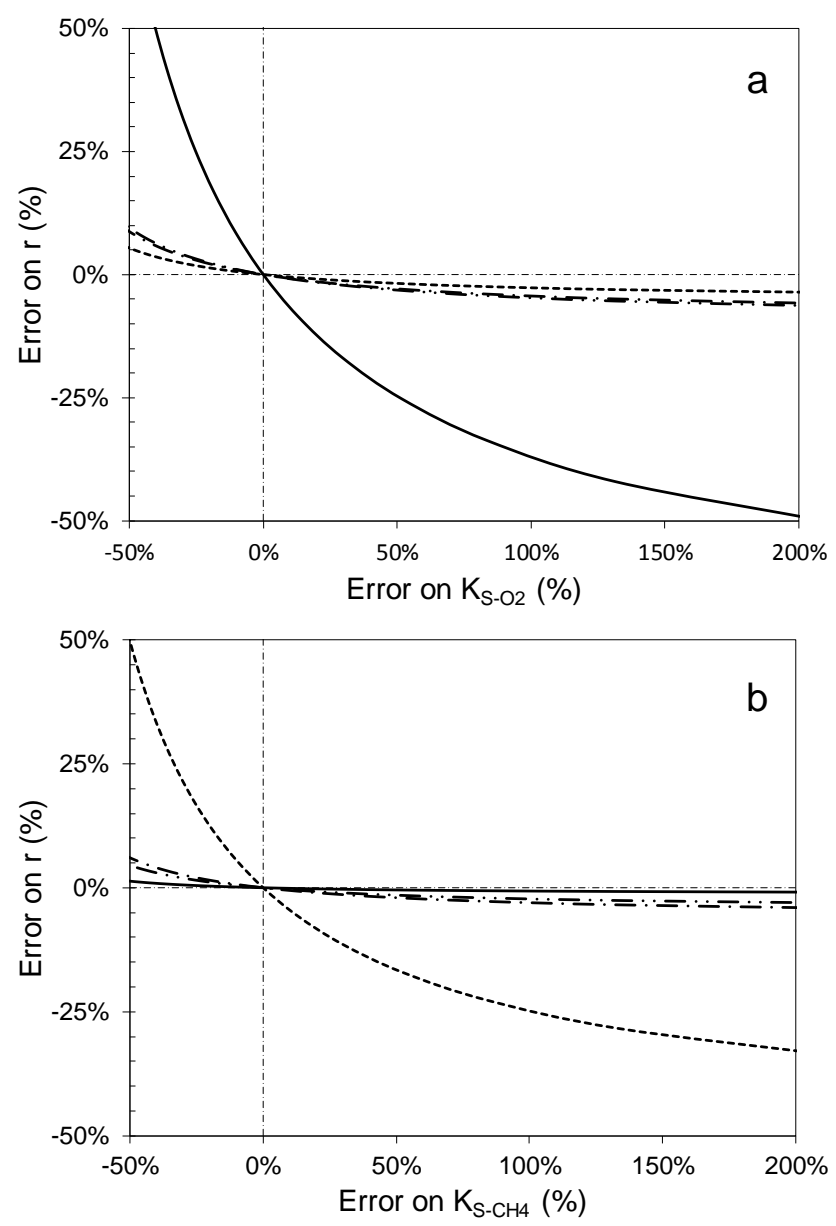

Figure 6. Sensitivity analysis of the impact of an error or variation in $K_{\mathrm{S}-\mathrm{O}_{2}}$ (a) and $K_{\mathrm{S}-\mathrm{CH}_{4}}$ (b) on $r$; yedoma lakes in winter (-), yedoma lakes in summer $(-\cdot-\cdot)$, non-yedoma lakes in winter $(-\cdot-\cdot \cdot)$ and non-yedoma lakes in summer (--- ).

et al., 2010; Schubert et al., 2010). Estimation of MO rates consistently measured at a single depth that was not necessarily located at the oxic/anoxic interface may have neglected potentially higher rates occurring at the oxic/anoxic interface in stratified lakes. However, in the present study, the sampled lakes were in many cases shallow, relatively well mixed, and without a clear oxycline (see Results section), suggesting a relatively homogeneous water column. Utsumi et al. (1998b) observed homogeneous MO rates at all depths of a shallow and mixed temperate lake, while Rudd and Hamilton (1978) also reported homogeneous MO rates during overturn of a dimictic lake. Determination of MO rates at the oxic/anoxic interface, in the few cases in which such an interface was observed, would likely have indicated higher MO rates. Thus, the results of $r$ presented here may be underestimated to an unknown extent. 


\section{Conclusions}

We developed a new method based on a TDLAS for the determination of $\mathrm{MO}$ rates together with dissolved $\mathrm{CH}_{4}$ concentration in lakes in the field. This method was successfully applied to 30 lakes along a north-south transect and allowed for the determination of MO potentials ranging from 0.000 to $1.339 \mathrm{mg} \mathrm{L}^{-1} \mathrm{~d}^{-1}$ in winter and summer. MO rates in water of Alaskan lakes showed high seasonal and geographic variability. In addition to temperature effects, the main factors controlling MO were: (1) $\mathrm{CH}_{4}$ availability during the summer, limited both by exchange with the atmosphere and by MO itself; (2) DO availability during the winter, mainly due to ice cover impeding gas exchange with the atmosphere and primary production; and (3) inputs of organic substrates to lakes, mainly related to the presence or absence of yedoma permafrost as an additional source of carbon and nutrients. These results indicate that MO may substantially mitigate the increase in $\mathrm{CH}_{4}$ emission predicted by permafrost thawing (Khvorostyanov, et al. 2008; Walter Anthony et al., 2014).

Acknowledgements. We thank D. Flores-Rojas and A. Strohm for their technical support and P. Anthony for preparing Fig. 2. This work was supported by the NSF OPP (\#1107892), NASA (\#NNX11AH20G), DOE (\#DE-SC0006920), and USGS, USA and Semarnat-Conacyt (\#23661), Mexico. We also gratefully acknowledge the Consejo Nacional de Ciencia y Tecnología, Mexico, for financial support to K. Martinez-Cruz, A. Sepulveda-Jauregui, and F. Thalasso (Grant no. 330197/233369, 206621/203709, and 139570, respectively). The authors declare that they have no conflicts of interest.

Edited by: I. Laurion

\section{References}

Bae, W. and Rittmann, B. E.: A structured model of dual-limitation kinetics, Biotechnol. Bioeng., 49, 683-689, 1996.

Bastviken, D., Ejlertsson, J., and Tranvik, L.: Measurement of methane oxidation in lakes: A comparison of methods, Environ. Sci. Technol., 36, 3354-3361, 2002.

Bastviken, D., Cole, J., Pace, M., and Tranvik, L.: Methane emissions from lakes: Dependence of lake characteristics, two regional assessments, and a global estimate, Global Biogeochem. Cy., 18, GB4009, doi:10.1029/2004GB002238, 2004.

Bastviken, D., Tranvik, L. J., Downing, J. A., Crill, P. M., and Enrich-Prast, A.: Freshwater Methane Emissions Offset the Continental Carbon Sink, Science, 331, 50-50, 2011.

Bellido, J. L., Peltomaa, E., and Ojala, A.: An urban boreal lake basin as a source of $\mathrm{CO}_{2}$ and $\mathrm{CH}_{4}$, Environ. Pollut., 159, 16491659, 2011.

Bender, M. and Conrad, R.: Effect of $\mathrm{CH}_{4}$ concentrations and soil conditions on the induction of $\mathrm{CH}_{4}$ oxidation activity, Soil Biol. Biochem., 27, 1517-1527, 1995.

Borrel, G., Jezequel, D., Biderre-Petit, C., Morel-Desrosiers, N., Morel, J. P., Peyret, P., Fonty, G., and Lehours, A. C.: Produc- tion and consumption of methane in freshwater lake ecosystems, Res. Microbiol., 162, 832-847, 2011.

Bowman, J. P., McCammon, S. A., and Skerratt J. H.: Methylosphaera hansonii gen nov, sp nov, a psychrophilic, group I methanotroph from Antarctic marine-salinity, meromictic lakes, Microbiology, 143, 1451-1459, 1997.

Branco, C. W. C., Kozlowsky-Suzuki, B., Sousa-Filho, I. F., Guarino, A. W. S., and Rocha, R. J.: Impact of climate on the vertical water column structure of Lajes Reservoir (Brazil): A tropical reservoir case, Lake Reserv. Manage., 14, 175-191, 2009.

Carini, S., Bano, N., LeCleir, G., and Joye, S. B.: Aerobic methane oxidation and methanotroph community composition during seasonal stratification in Mono Lake, California (USA), Environ. Microbiol., 7, 1127-1138, 2005.

Clilverd, H., White, D., and Lilly, M.: Chemical and physical controls on the oxygen regime of ice-covered arctic lakes and reservoirs, J. Am. Water Resour. As., 45, 500-511, 2009.

Czudek, T. and Demek, J.: Thermokarst in Siberia and its influence on the development of lowland relief, Quaternary Res., 1, 103120, 1970.

Dunfield, P. F., Liesack, W., Henckel, T., Knowles, R., and Conrad, R.: High-affinity methane oxidation by a soil enrichment culture containing a type II methanotroph, Appl. Environ. Microb., 65, 1009-1014, 1999.

Dzyuban, A. N.: Dynamics of microbial oxidation of methane in the water of stratified lakes, Microbiology, 79, 822-829, 2010.

Frenzel, P., Thebrath, B., and Conrad, R.: Oxidation of methane in the oxic surface-layer of a deep lake sediment (Lake Constance), Fems Microbiol. Ecol., 73, 149-158, 1990.

Gentzel, T., Hershey, A. E., Rublee, P. A., and Whalen, S. C.: Net sediment production of methane, distribution of methanogens and methane-oxidizing bacteria, and utilization of methanederived carbon in an arctic lake, Inland Waters, 2, 77-88, 2012.

Greene, S., Walter Anthony, K. M., Archer, D., Sepulveda-Jauregui, A., and Martinez-Cruz, K.: Modeling the impediment of methane ebullition bubbles by seasonal lake ice, Biogeosciences, 11, 6791-6811, doi:10.5194/bg-11-6791-2014, 2014.

Gregory-Eaves, I., Smol, J. P., Finney, B. P., Lean, D. R. S., and Edwards, M. E.: Characteristics and variation in lakes along a north-south transect in Alaska, Arch. Hydrobiol., 147, 193-223, 2000.

Grosse, G., Jones, B., and Arp, C.: Thermokarst lakes, drainage, and drained basins, in: Treatise on Geomorphology, edited by: Shroder, J. F., Giardino, R., and Harbor, J., Glacial and Periglacial Geomorphology, Academic Press, San Diego, 8, 325353, 2013.

Heslop, J. K., Walter Anthony, K. M., Sepulveda-Jauregui, A., Martinez-Cruz, K., Bondurant, A., Grosse, G., and Jones, M. C.: Thermokarst lake methanogenesis along a complete talik profile, Biogeosciences, 12, 4317-4331, doi:10.5194/bg-12-4317-2015, 2015.

He, R., Wooller, M. J., Pohlman, J. W., Quensen, J., Tiedje, J. M., and Leigh, M. B.: Diversity of active aerobic methanotrophs along depth profiles of arctic and subarctic lake water column and sediments, ISME J., 6, 1937-1948, 2012.

Hugelius, G., Strauss, J., Zubrzycki, S., Harden, J. W., Schuur, E. A. G., Ping, C.-L., Schirrmeister, L., Grosse, G., Michaelson, G. J., Koven, C. D., O’Donnell, J. A., Elberling, B., Mishra, U., Camill, P., Yu, Z., Palmtag, J., and Kuhry, P.: Estimated stocks 
of circumpolar permafrost carbon with quantified uncertainty ranges and identified data gaps, Biogeosciences, 11, 6573-6593, doi:10.5194/bg-11-6573-2014, 2014.

Jones, R. I. and Grey, J.: Biogenic methane in freshwater food webs, Freshwater Biol., 56, 213-229, 2011.

Jorgenson, T., Yoshikawa, K., Kanevskiy, M., Shur, Y., Romanovsky, V., Marchenko, S., Grosse, G., Brown, J., and Jones, B.: Permafrost Characteristics of Alaska. Institute of Northern Engineering, University of Alaska Fairbanks NICOP, University of Alaska Fairbanks, USA, 2008.

Juutinen, S., Rantakari, M., Kortelainen, P., Huttunen, J. T., Larmola, T., Alm, J., Silvola, J., and Martikainen, P. J.: Methane dynamics in different boreal lake types, Biogeosciences, 6, 209223, doi:10.5194/bg-6-209-2009, 2009.

Kanevskiy, M., Shur, Y., Fortier, D., Jorgenson, M. T., and Stephani, E.: Cryostratigraphy of late Pleistocene syngenetic permafrost (yedoma) in northern Alaska, Itkillik River exposure, Quaternary Res., 75, 584-596, 2011.

Kankaala, P., Huotari, J., Peltomaa, E., Saloranta, T., and Ojala, A.: Methanotrophic activity in relation to methane efflux and total heterotrophic bacterial production in a stratified, humic, boreal lake, Limnol. Oceanogr., 51, 1195-1204, 2006.

Kankaala, P., Taipale, S., Nykanen, H., and Jones, R. I.: Oxidation, efflux, and isotopic fractionation of methane during autumnal turnover in a polyhumic, boreal lake, J. Geophy. Res.-Biogeo., 112, G02003, doi:10.1029/2006JG000336, 2007.

Khvorostyanov, D. V., Ciais, P., Krinner, G., Zimov, S. A., Corradi, C., and Guggenberger, G.: Vulnerability of permafrost carbon to global warming. Part II: sensitivity of permafrost carbon stock to global warming, Tellus B, 60, 265-275, 2008.

Kovarova-Kovar, K. and Egli, T.: Growth kinetics of suspended microbial cells: from single-substrate-controlled growth to mixedsubstrate kinetics, Microbiol. Mol. Biol. Rev., 62, 646-666, 1998.

Lidstrom, M. E. and Somers, L.: Seasonal study of methane oxidation in lake Washington, Appl. Environ. Microb., 47, 1255-1260, 1984.

Liikanen, A., Huttunen, J. T., Valli, K., and Martikainen, P. J.: Methane cycling in the sediment and water column of mid-boreal hyper-eutrophic Lake Kevaton, Finland, Arch. Hydrobiol., 154, 585-603, 2002.

Lofton, D. D., Whalen, S. C., and Hershey, A. E.: Effect of temperature on methane dynamics and evaluation of methane oxidation kinetics in shallow Arctic Alaskan lakes, Hydrobiologia, 721, 209-222, 2014.

Martinez-Cruz, K., Sepulveda-Jauregui, A., Escobar-Orozco, N., and Thalasso, F.: Methanogenic activity tests by Infrared Tunable Diode Laser Absorption Spectroscopy, J. Microbiol. Meth., 91, 89-92, 2012.

Murrell, J. C., McGowan, V., and Cardy, D. L. N.: Detection of methylotrophic bacteria in natural samples by molecular probing techniques, Chemosphere, 26, 1-11, 1993.

Omelchenko, M. V., Vasilyeva, L. V., and Zavarzin, G. A.: Psychrophilic methanotrophs from tundra soil, Curr. Microbiol., 27, 255-259, 1993.

Omelchenko, M. V., Vasileva, L. V., Zavarzin, G. A., Saveleva, N. D., Lysenko, A. M., Mityushina, L. L., Kamelenina, V. N., and Trotsenko, Y. A.: A novel psychrophilic methanotroph of the genus Methylobacter, Microbiology, 65, 339-343, 1996.
Padisak, J., Barbosa, F., Koschel, R., and Krienitz, L.: Deep layer cyanoprokaryota maxima in temperate and tropical lakes, Arch. Hydrobiol., 58, 175-199, 2003.

Phelps, A. R., Peterson, K. M., and Jeffries, M. O.: Methane efflux from high-latitude lakes during spring ice melt, J. Geophys. Res.Atmos., 103, 29029-29036, 1998.

Pimenov, N. V., Kallistova, A. Y., Rusanov, I. I., Yusopov, S. K., Montonen, L., Jurgens, G., Munster, U., Nozhevnikova, A. N., and Ivanov, M. V.: Methane formation and oxidation in the meromictic oligotrophic Lake Gek-Gel (Azerbaijan), Microbiology, 79, 247-252, 2010.

Ping, C. L., Michaelson, G. J., Jorgenson, M. T., Kimble, J. M., Epstein, H., Romanovsky, V. E., and Walker, D. A.: High stocks of soil organic carbon in the North American Arctic region, Nat. Geosci., 1, 615-619, 2008.

Rudd, J. W. M. and Hamilton, R. D.: Methane Cycling in a Eutrophic Shield Lake and Its Effects on Whole Lake Metabolism, Limnol. Oceanogr., 23, 337-348, 1978.

Schubert, C. J., Lucas, F. S., Durisch-Kaiser, E., Stierli, R., Diem, T., Scheidegger, O., Vazquez, F., and Muller, B.: Oxidation and emission of methane in a monomictic lake (Rotsee, Switzerland) Aquat. Sci., 72, 455-466, 2010.

Segers, R.: Methane production and methane consumption: a review of processes underlying wetland methane fluxes, Biogeochemistry, 41, 23-51, 1998.

Seifert, L. I. and Scheu, S.: Linking aquatic and terrestrial food webs - Odonata in boreal systems, Freshwater Biol., 57, 14491457, 2012.

Semrau, J. D., DiSpirito, A. A., and Murrell J. C.: Life in the extreme: thermoacidophilic methanotrophy, Trends Microbiol., 16, 190-193, 2008.

Semrau, J. D., DiSpirito, A. A., and Yoon, S.: Methanotrophs and copper, Fems Microbiol. Rev., 34, 496-531, 2010.

Sepulveda-Jauregui, A., Martinez-Cruz, K., Strohm, A., Anthony, K. M. W., and Thalasso, F.: A new method for field measurement of dissolved methane in water using infrared tunable diode laser absorption spectroscopy, Limnol. Oceanogr.-Methods, 10, 560$567,2012$.

Sepulveda-Jauregui, A., Walter Anthony, K. M., Martinez-Cruz, K., Greene, S., and Thalasso, F.: Methane and carbon dioxide emissions from 40 lakes along a north-south latitudinal transect in Alaska, Biogeosciences, 12, 3197-3223, doi:10.5194/bg-123197-2015, 2015.

Smith, S. L., Romanovsky, V. E., Lewkowicz, A. G., Burn, C. R., Allard, M., Clow, G. D., Yoshikawa, K., and Throop, J.: Thermal State of Permafrost in North America: A Contribution to the International Polar Year, Permafrost Periglac., 21, 117-135, 2010.

Taipale, S. J., Brett, M. T., Pulkkinen, K., and Kainz, M. J.: The influence of bacteria-dominated diets on Daphnia magna somatic growth, reproduction, and lipid composition, Fems Microbiol. Ecol., 82, 50-62, 2012.

Tan, Z., Zhuang, Q., Walter Anthony, K. M.: Modeling methane emissions from arctic lakes: model development and site-level study, J. Adv. Model. Earth Sy., 07, doi:10.1002/2014MS000344, 2015.

Tarnocai, C., Canadell, J. G., Schuur, E. A. G., Kuhry, P., Mazhitova, G., and Zimov, S.: Soil organic carbon pools in the northern circumpolar permafrost region, Global Biogeochem. Cy., 23, GB2023, doi:10.1029/2008GB003327, 2009. 
Thauer, R. K., Kaster, A. K., Seedorf, H., Buckel, W., and Hedderich, R.: Methanogenic archaea: ecologically relevant differences in energy conservation, Nat. Rev. Microbiol., 6, 579-591, 2008.

Trotsenko, Y. A. and Khmelenina, V. N.: Biology of extremophilic and extremotolerant methanotrophs, Arch. Microbiol., 177, 123$131,2002$.

Trotsenko, Y. A. and Murrell, J. C.: Metabolic aspects of aerobic obligate methanotrophy, Adv. Appl. Microbiol., 63, 183-229, 2008.

Utsumi, M., Nojiri, Y., Nakamura, T., Nozawa, T., Otsuki, A., Takamura, N., Watanabe, M., and Seki, H.: Dynamics of dissolved methane and methane oxidation in dimictic Lake Nojiri during winter, Limnol. Oceanogr., 43, 10-17, 1998a.

Utsumi, M., Nojiri, Y., Nakamura, T., Nozawa, T., Otsuki, A., and Seki, H.: Oxidation of dissolved methane in a eutrophic, shallow lake: Lake Kasumigaura, Japan, Limnol. Oceanogr., 43, 471480, 1998b.

Walter, K. M., Zimov, S. A., Chanton, J. P., Verbyla, D., and Chapin, F. S.: Methane bubbling from Siberian thaw lakes as a positive feedback to climate warming, Nature, 443, 71-75, 2006.

Walter, K. M., Smith, L. C., and Chapin, F. S.: Methane bubbling from northern lakes: present and future contributions to the global methane budget, Philos. T. R. Soc. A., 365, 1657-1676, 2007.

Walter Anthony, K. M. and Anthony, P.: Constraining spatial variability of methane ebullition seeps in thermokarst lakes using point process models, J. Geophys. Res.-Biogeo., 118, 10151034, 2013.
Walter Anthony, K. M., Zimov S. A., Grosse, G., Jones, M. C., Anthony, P., Chapin III, F. S., Finlay, J. C., Mack, M. C., Davydov, S., Frenzel, P., and Frolking S.: A shift of thermokarst lakes from carbon sources to sinks during the Holocene epoch, Nature, 511, 452-456, doi:10.1038/nature13560, 2014.

Whalen, S. C., Reeburgh, W. S., and Sandbeck, K. A.: Rapid methane oxidation in a ladfill cover soil, Appl. Environ. Microb., 56, 3405-3411, 1990.

White, D. M., Clilverd, H. M., Tidwell, A. C., Little, L., Lilly, M. R., Chambers, M., and Reichardt, D.: A tool for modeling the winter oxygen depletion rate in arctic lakes, J. Am. Water Resour. As. 44, 293-304, 2008.

Wooller, M. J., Pohlman, J. W., Gaglioti, B. V., Langdon, P., Jones, M., Anthony, K. M. W., Becker, K. W., Hinrichs, K. U., and Elvert, M.: Reconstruction of past methane availability in an Arctic Alaska wetland indicates climate influenced methane release during the past $\sim 12000$ years, J. Paleolimnol., 48, 27-42, 2012

Zimov, S. A., Voropaev, Y. V., Semiletov, I. P., Davidov, S. P., Prosiannikov, S. F., Chapin, F. S., Chapin, M. C., Trumbore, S., and Tyler, S.: North Siberian lakes: A methane source fueled by Pleistocene carbon, Science, 277, 800-802, 1997.

Zimov, S. A., Schuur, E. A. G., and Chapin III, F. S.: Permafrost and the Global Carbon Budget, Science, 312, 1612-1613, 2006. 